\title{
Ação Bacteriolítica dos Fosfatos (Fosfatólise Bacteriana)
}

\author{
Genesio Pacheco e Vinicius Moreira Dias
}

Anteriormente Pacheco e Abreu (3) observaram um efeito lítico de una água mineral radioativa sôbre certas bactérias e Pacheco \& Échaniz (4) compararam a atividade bacteriolitica do $\mathrm{Na}_{2} \mathrm{HPO}_{4} \cdot 2 \mathrm{H}_{2} \mathrm{O}$ sôbre Salmonella typhosa e Escherichia coli.

No presente trabalho procurou-se observar as possive:s diferenças na atividade de vários fosfatos.

\section{MATERIAL E MÉTODO}

Os sais usados foram $\mathrm{Na}_{2} \mathrm{HPO}_{4} \cdot \mathrm{H}_{2} \mathrm{O}, \mathrm{Na}_{2} \mathrm{HPO}_{4} .2 \mathrm{H}_{2} \mathrm{O}, \mathrm{Na}_{3} \mathrm{HPO}_{4}$. $12 \mathrm{H}_{2} \mathrm{O}$ e $\mathrm{K}_{2} \mathrm{HPO}_{4} . \mathrm{H}_{2} \mathrm{O}$, em soluções $\mathrm{M} / 10, \mathrm{M} / 50, \mathrm{D} / 100, \mathrm{M} / 500, \mathrm{M} / 1000$ ou $1 / 100$ e $1 / 1000$.

Os germens usados foram a $S$. typhosa amostra H901, E. coli e Micrococcus pyogenes var. aureus, de nossa coleção de culturas. Germens crescidos em agar inclinado, durante 24 horas, eram suspensos e lavados 2 vezes em águas fisiológica, depois preparadas suspensões de modo a obter concentrações adequadas.

As soluções de fosfato eram distribuidas em tubos Kimble de $13 \times 100 / \mathrm{mm}$, apropriados ao colorimetro fotoelétrico de Klett- Summerson. A concenleitura aproximada de 100 ou mais do colorimetro, usando o filtro verde lisadas todos os dias e os resultados referidos à leitura inicial com aumento $(540 \mathrm{~m} \mu)$, utilisando a solução fosfatada como blank. As leituras eram realisadas todos os dias e os resultados referidos à leitura inicial com aumento ou decréscimo da opacidade. Mantinham se os tubos com as suspensões na temperatura ambiente e no final verificava-se a viabilidade dos germens. De outras vezes os germens eram prëviamente mortos e conservados em tubos fechados a lampada.

\section{RESULTADOS}

Mostraram as experiências com $\mathrm{Na}_{2} \mathrm{HPO}_{4}, 2 \mathrm{H}_{2} \mathrm{O}$ 1/100 e 1/1000, com $M$. pyogenes e $E$. coli que êste sal exercia nitida ação bacteriolitica sôbre - $M$. piogenes nas concentrações usadas, quer nos tubos fechados quer nos abertes, na temperatura ambiente ou a $39^{\circ}$, vivos ou mortos (pelo eter). Figs. 1 e 2. Sôbre a $E$. coli a atividade foi menos intensa. Figs. 3 e 4.

Com $\mathrm{NaH}_{2} \mathrm{PO}_{4} \cdot \mathrm{H}_{2} \mathrm{O}$ em várias concentrações o efeito variou com os diferentes germens utilisados: a $S$. typhosa foi lisada em todas concentrações usadas, embora menos que na agua destilada (Fig. 5); a E. coli foi lisada 
mais intensamente na solução $1 / 100$ e $1 / 1000$ e menos nas outras cnncentrações (Fig. 6). M. pyogenes se mostrou lisado no mesmo grau que na água destilada (Fig. 7) . Em outras experiências preliminares, no entanto, as concentrações mais fracas se mostraram mais bacterioliticas.

$\mathrm{O} \mathrm{pH}$ das soluções medido com eletrode de vidro foi: $\mathrm{M} / 10,4.5 ; \mathrm{M} / 50$, 4.75; M/100, 4.92; M/500, 5.07; M/1000, 5.32.

Com $\mathrm{Na}_{3} \mathrm{HPO}_{4}, \mathrm{H}_{2} \mathrm{O}$, os resultados foram um tanto diferentes dos alcançados com o $\mathrm{NaH}_{2} \mathrm{PO}_{4} \cdot \mathrm{H}_{2} \mathrm{O}$ : a $S$. typhosa foi menos lisada que na água destilada, tal qual foi obtido com o $\mathrm{NaH}_{2} \mathrm{PO}_{4} \cdot \mathrm{H}_{2} \mathrm{O}$ (Fig. 8); a E. coli, entretanto foi fortemente lisada em tôdas as concentrações, sendo mais ativas as mais concentradas; $M$. pyogenes foi totalmente lisado em solução $\mathrm{M} / 100$ e $\mathrm{M} / 1000$ (Fig. 10). $\mathrm{O} \mathrm{pH}$ destas soluções foi : $\mathrm{M} / 10,11,4$; $\mathrm{M} / 50,11.5 ; \mathrm{M} / 100,11.35 ; \mathrm{M} / 500,9.6 ; \mathrm{M} / 1000,7.43$.

Anteriormente vimos que os microrganismos mortos eram intensamente lisados em presença de solução de $\mathrm{Na}_{2} \mathrm{HPO}_{1} .2 \mathrm{H}_{2} \mathrm{O}$. Por isso empregamos 3 tipos de fosfatos em solução M10 e M/100 (Fig. 11-12-13). Os mir crorganismos eram mortos pelo eter que era evaporado durante uma noite na estufa e em seguida suspensos nas soluções de fosfatos. Os germens vivos eram suspensos em água destilada para comparação (Fig. 14).

\section{DISCUSSÃO}

Lise de bactérias pode resultar de anticorpos, envelhecimento, morte, bem como de agentes químicos. De qualquer modo a lise resulta sempre da ruptura da parede celular.

A primeira observação da lise bacteriana pelos fosfatos foi de EvangeLiNos $\mathcal{E}$ Wohlfeil (1) com a $E$. coli. Mediram êles a lise pelo acréscimo do teor de proteinas dos filtrados das suspensões bacterianas em soluções de fosfato de sódio $\mathrm{M} / 15, \mathrm{M} / 30$ e $\mathrm{M} / 6 \$$, tendo se revelado ativas tôdas elas. O Proteus foi menos lisado nas concentrações mais fracas. A lise foi vista mais forte em temperatura entre 37 45\%.

Welsch, Salmon E Heusghen (9) observaram que a lise expontânea do estafilococo pela "estafilolisina" era incrementada com a adição de fosfato de potássio 0,1 por cento. Removendo o fasfato pelo carbonato de bár:o a lise permanecia.

WeLSCH E SALMON (8) viram ainda que o fosfato dispotássico ativara líquidos inativos ou pouco ativos, pela excessiva diluição. sendo o fosfato monopotássico menos ativo. Bactérias mortas foram lisadas como as vivas, revelando que o fenômeno deve ser diferente do referido por WELSCH.

WelsCh E SALMON (8) verificaram que suspensões de estafilococos lavadas 3 vezes quase não eram lisadas mas que a junção de 0.1 por cento de fosfato d'ssódico determina rápida lise o que interpretaram como um efeito ativo do fosfato sôbre o principio lítico (ou fermento) que se revelou necessário à bacteriólise. Por outro lado o lavamento bacteriano reduz enormemente a ação lítica do seu «fermento», que pode ser reativado pelo fosfato, como quer WELSCH (7).

Os trabalhos de Welsch e seus colaboradores admitem a existência de uma bacteriolisina a qual pode ser inespecifica segundo SMOLIER (5) ou específica como quer WELSCH (7). 
Nossos resultados mostraram uma atividade bacteriolítica de vários fosfatos, algumas vezes bastante intensa. As observações de WELSCH \& SALMON (8) de lise expontânea foram feitos com líquidos contendo fosfatos, salvo quando êste foi eliminado por tratamento químico mas póde ter havido uma penetração intracelular prévia do fosfato antes da sua eliminação do líquido que o continha.

Nossas observações acêrca da ação lítica dos fosfatos em diluições fracas, parece-nos de importância, pois observa-se algumas vezes o desaparecimento de germens nas culturas em caldo que contenha fosfatos. Observaram MELlo \& Col., (2) por exemplo, rápido desaparecimento de brucelas em meios contendo fosfatos como tampão.

Certos cocos Gram positivos são particularmente sensiveis à fosfatolise e é frequente a observação de seu desaparecimento nas hemoculturas em meios liquidos.

\section{RESUMO}

1) As bactérias são lisadas pelos fosfatos, cuja atividade lítica varia com o sal de fosfato, os trivalentes sendo mais ativos.

2) A fosfatólise independente da viabilidade da bactéria.

3) A fosfatólise póde interferir nas suspensões com tampões de fos fatos e na preservação de hemoculturas.

M. pyogenenes, var aureus DEAD $-37^{\circ} \mathrm{C}$

(See remarks of fig. 3)

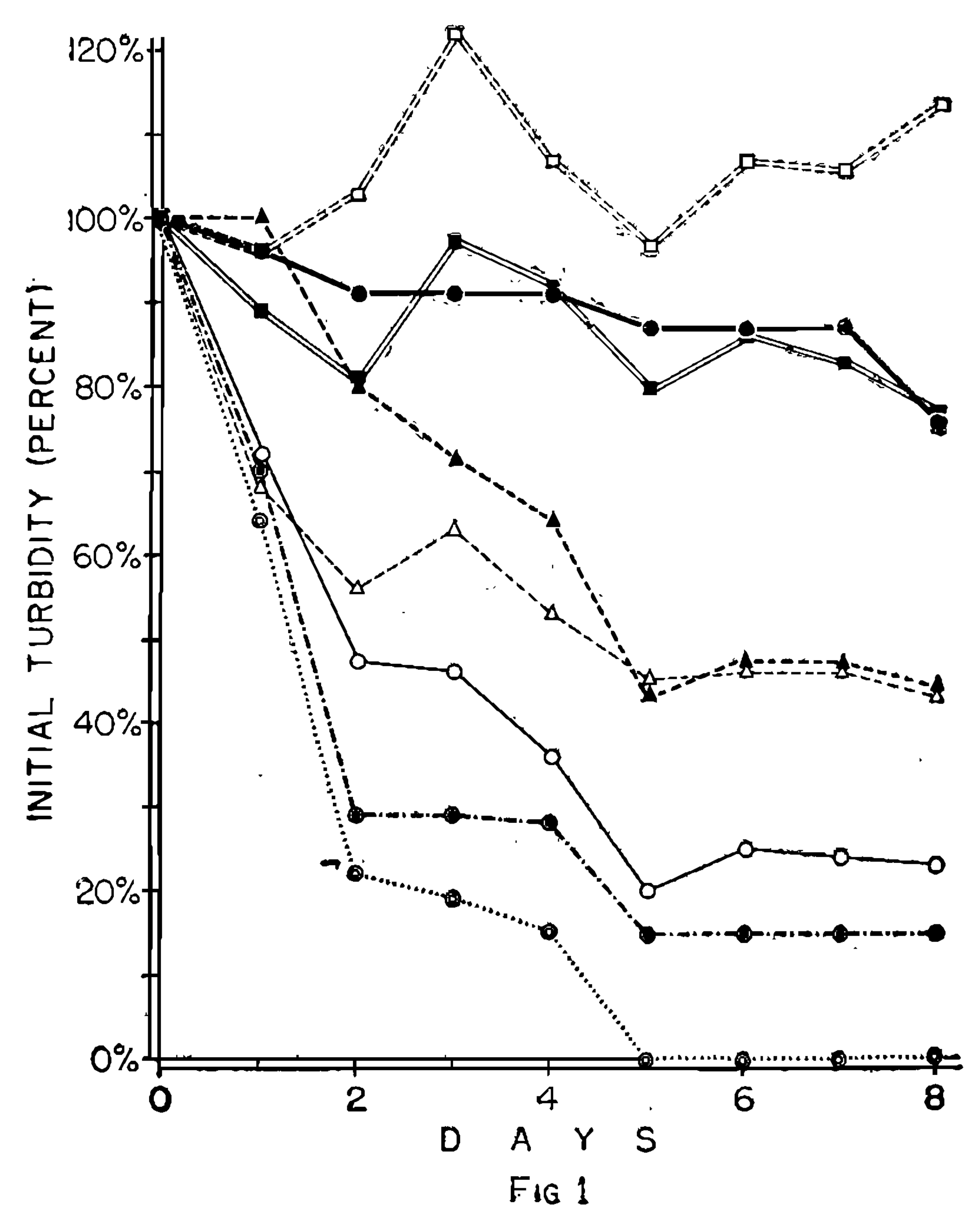

M. pyogenes, var. aureus ALIVE - ROOM TEMPERATURE (See remorks of fig 3)

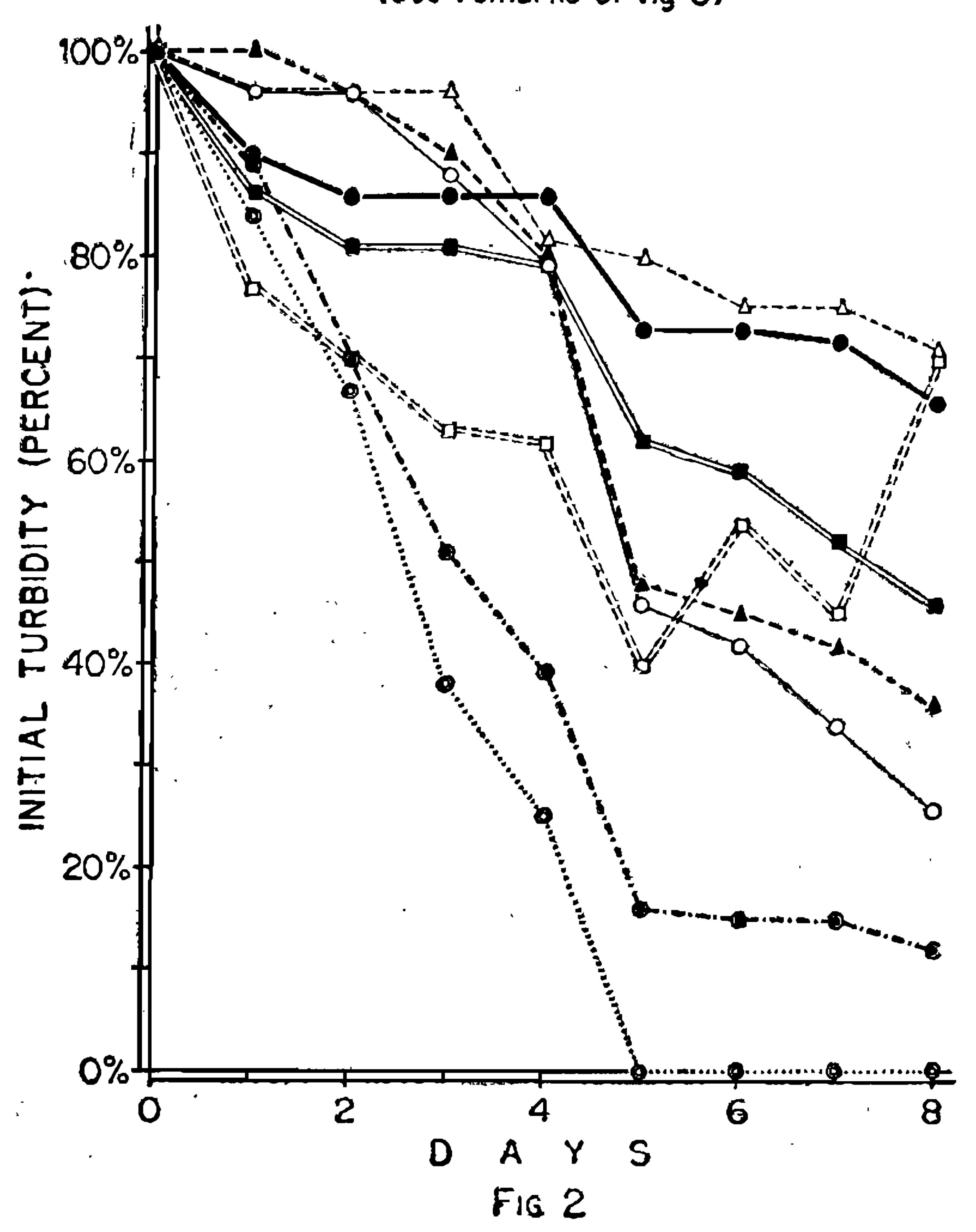




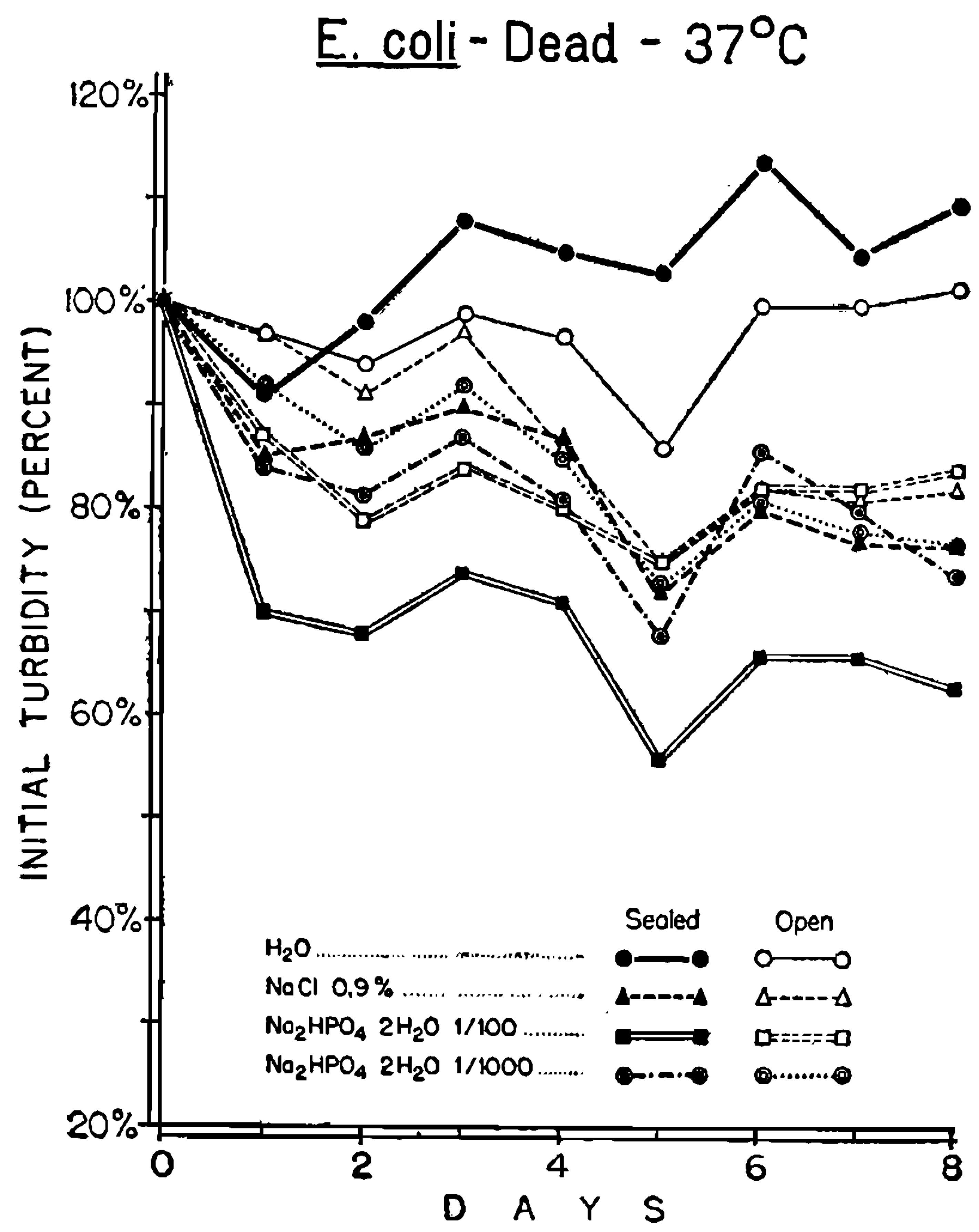

FIG. 3

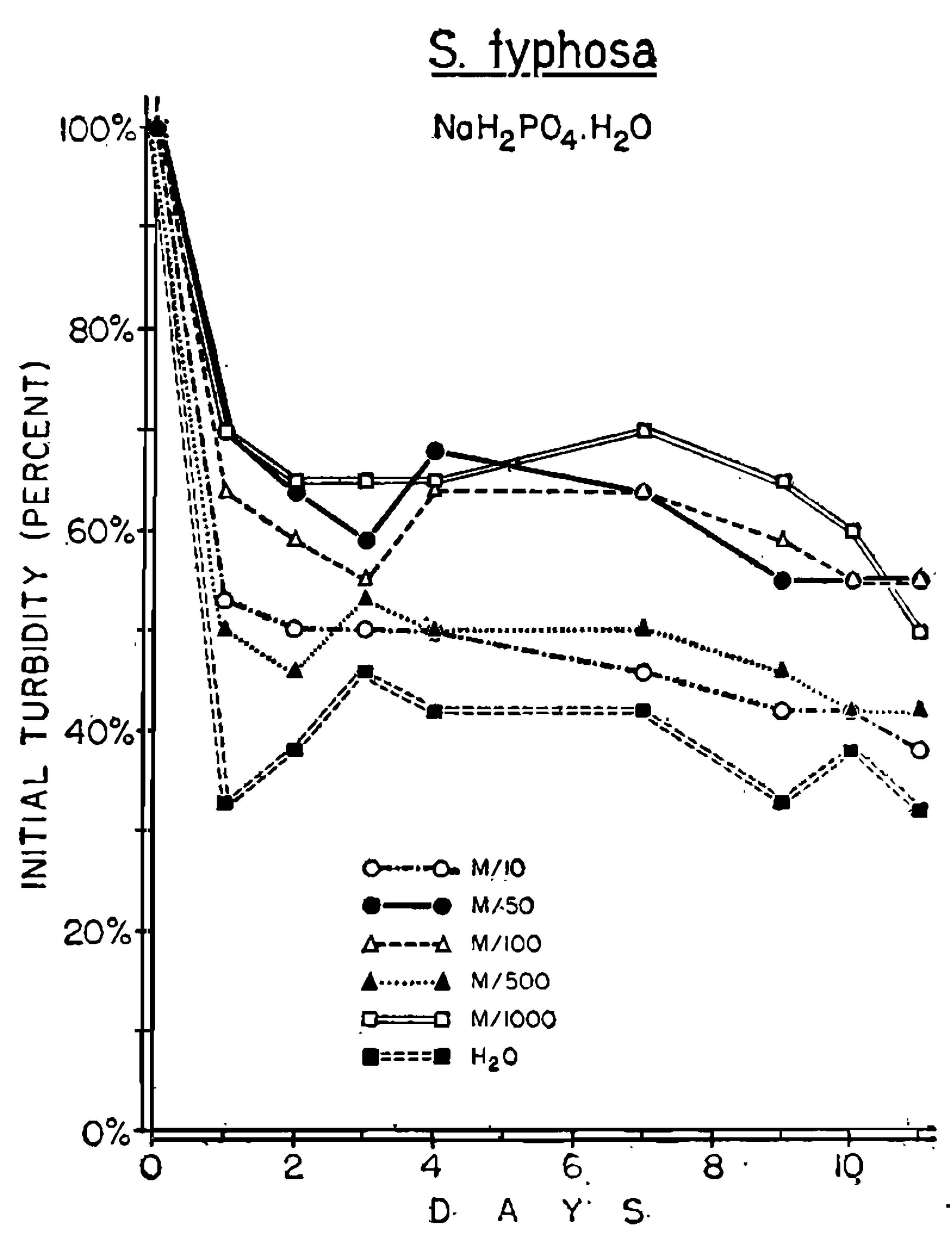

F. 5

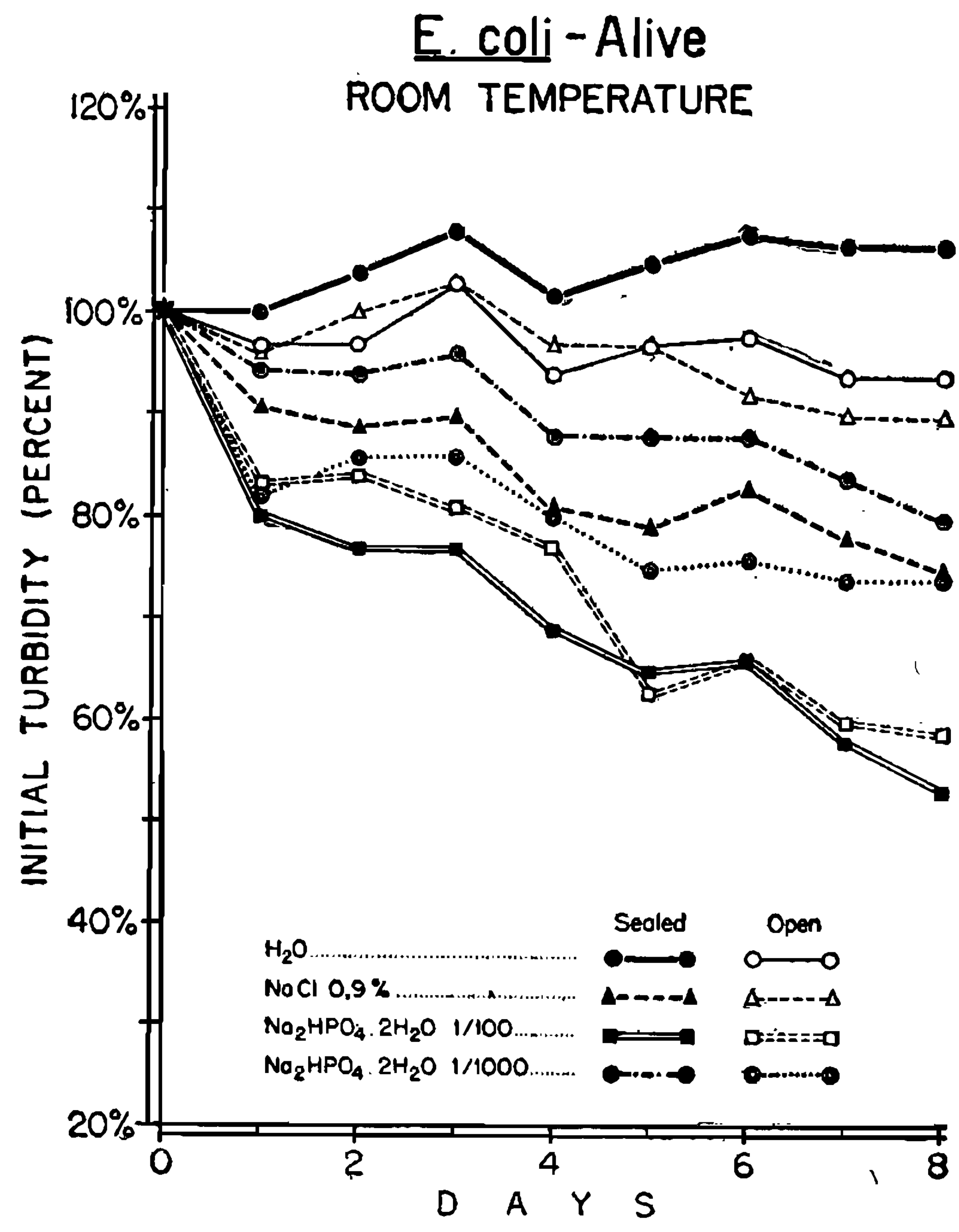

FiG. 4

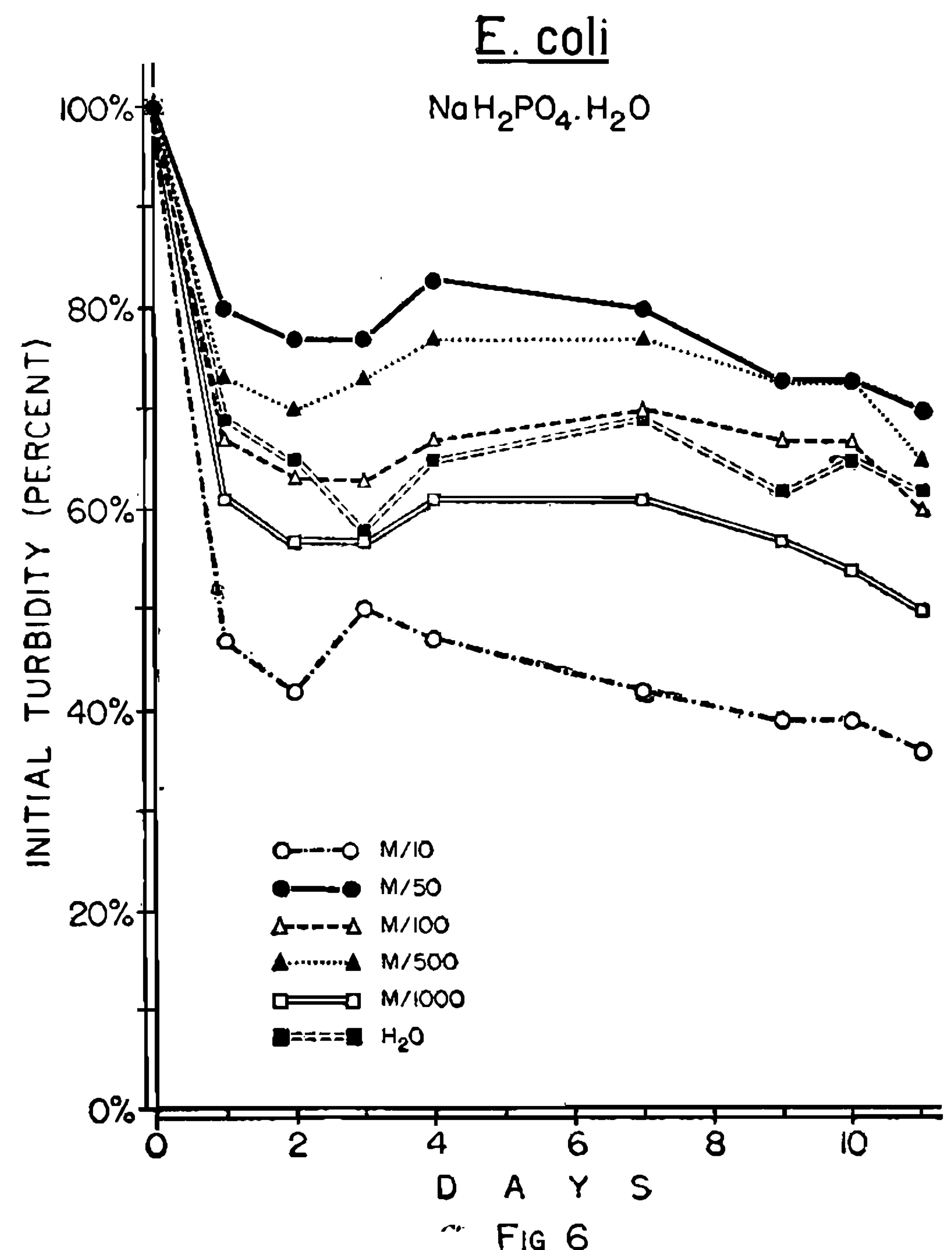




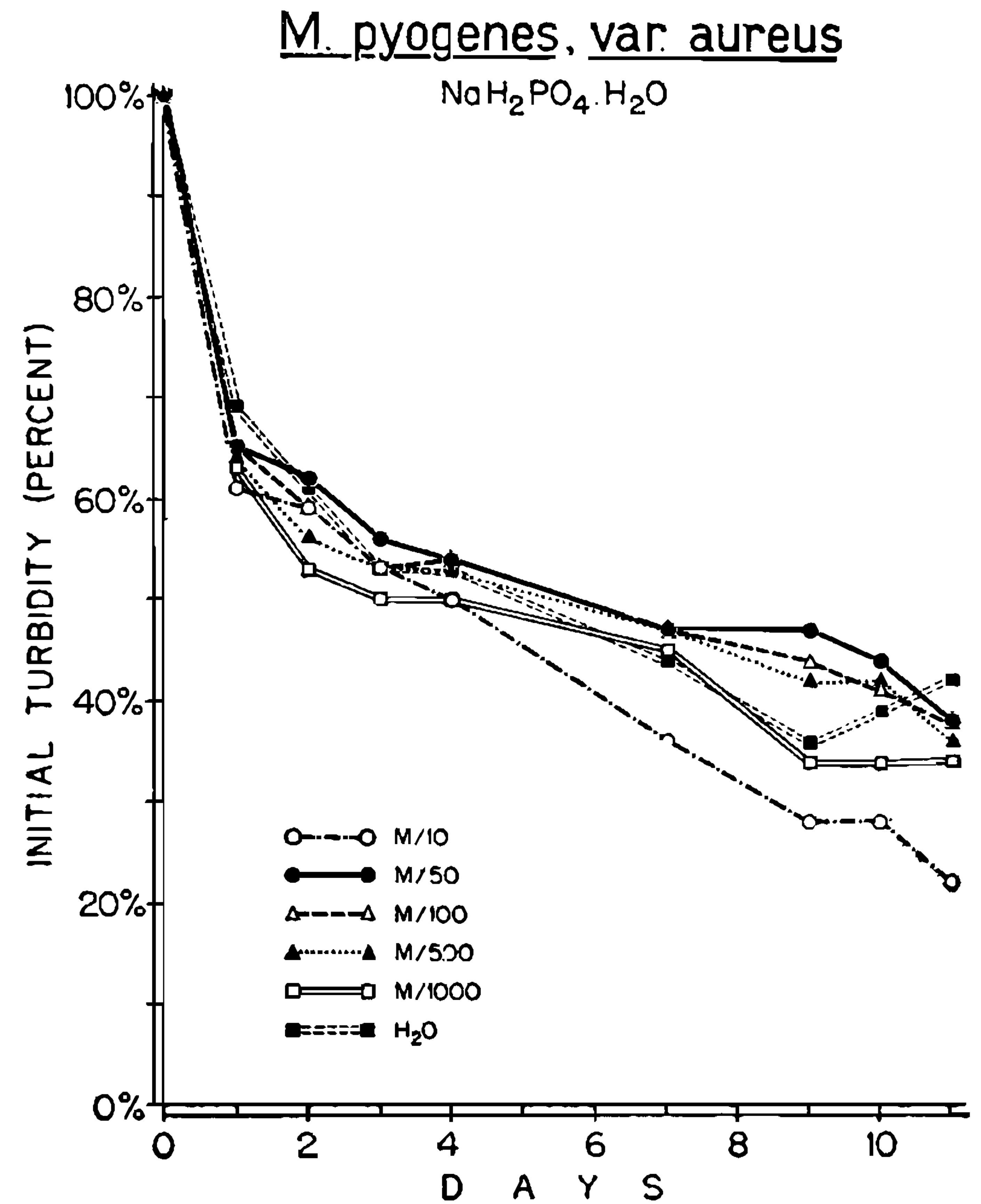

FIG. 7

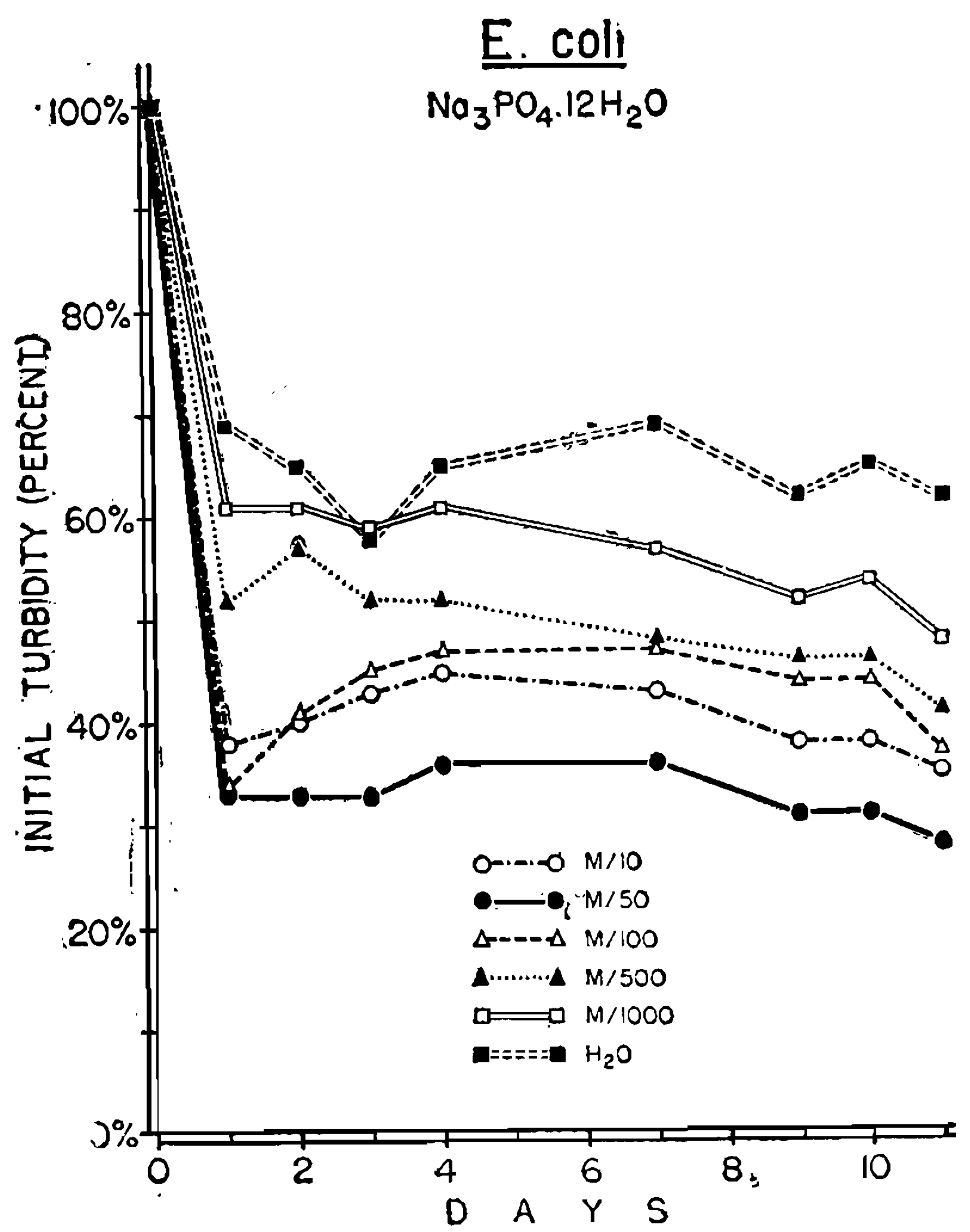

FIG. 9

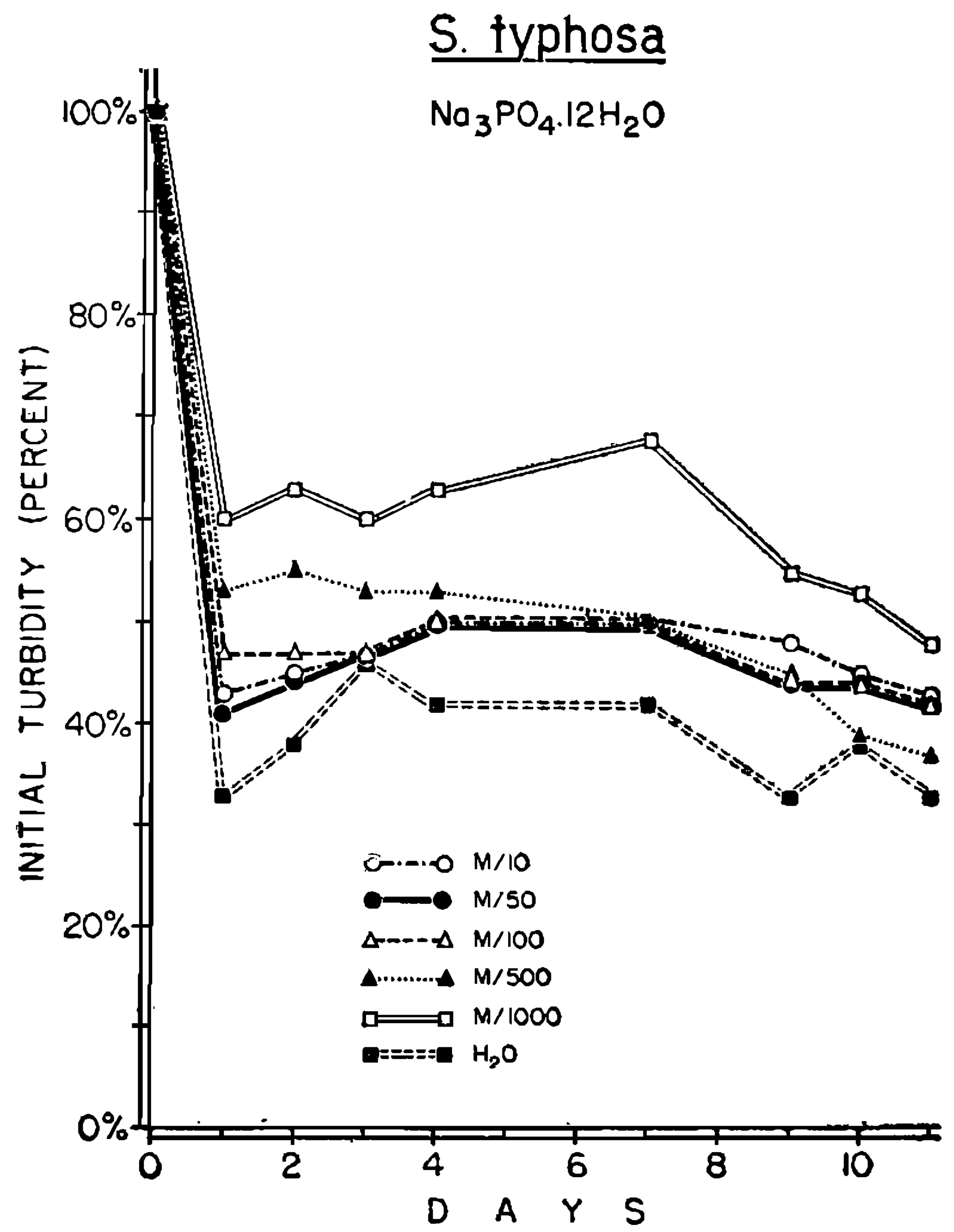

FIG. 8

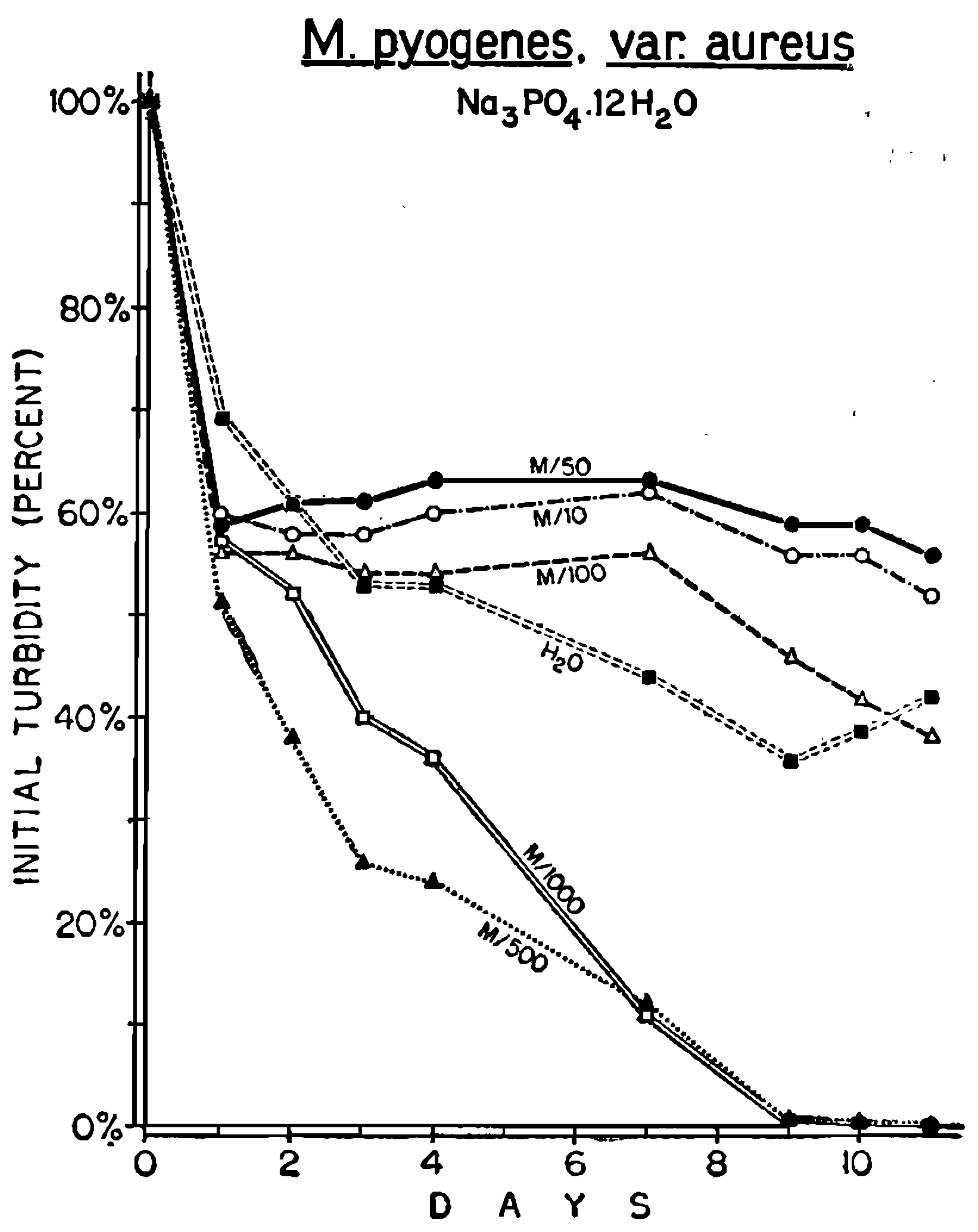

FIG. 10 


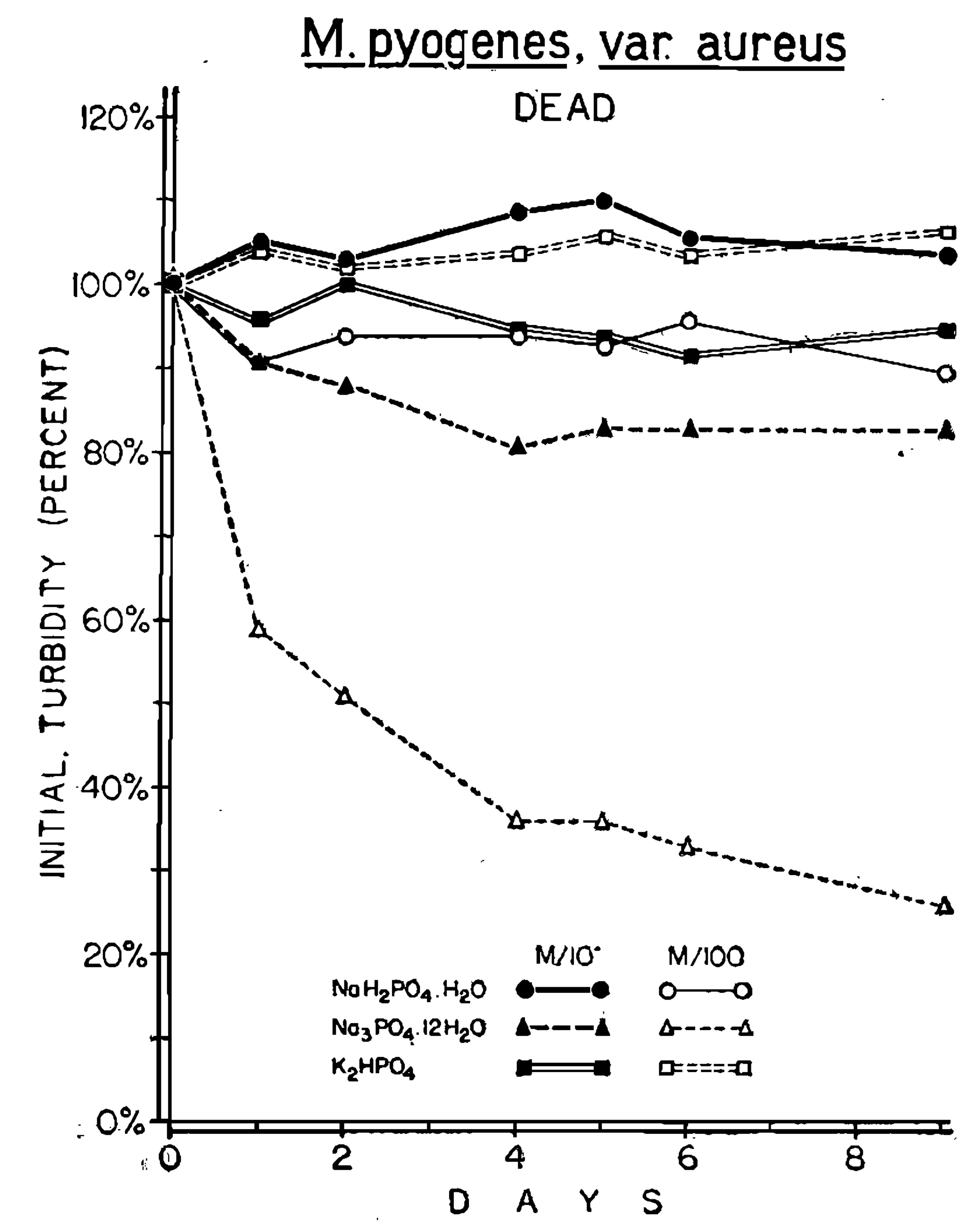

FIG 11

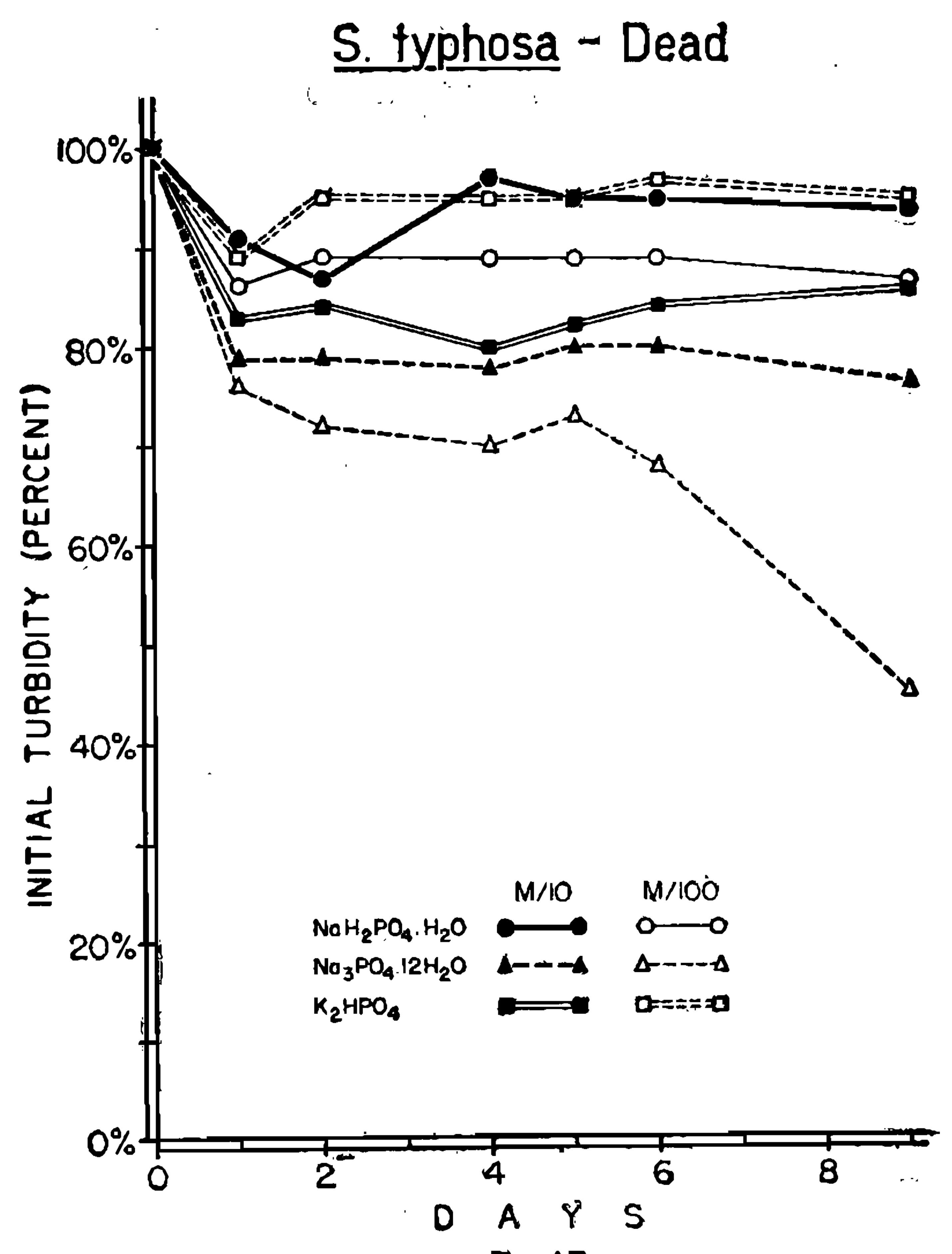

EIG. 13

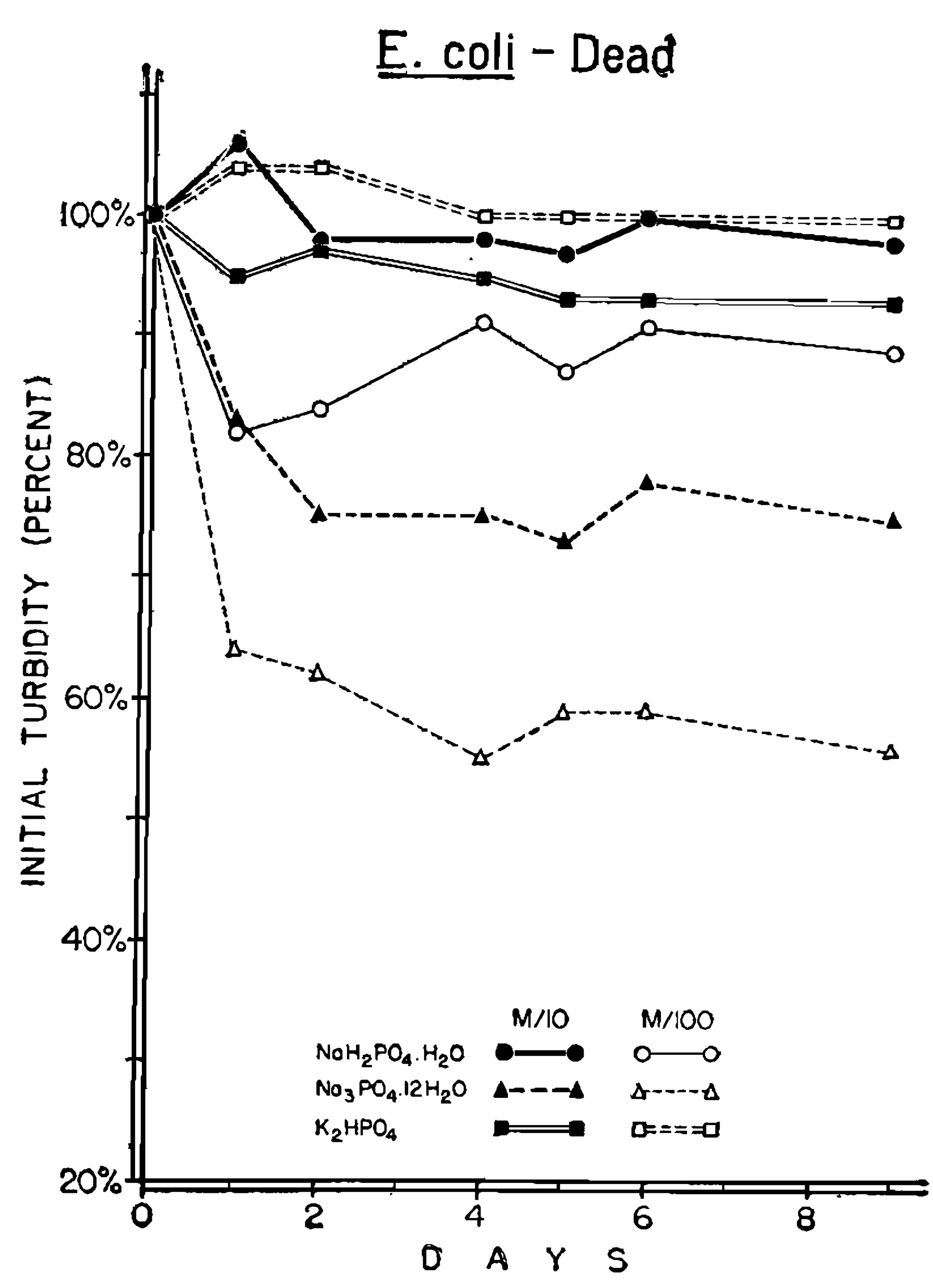

FIG.12

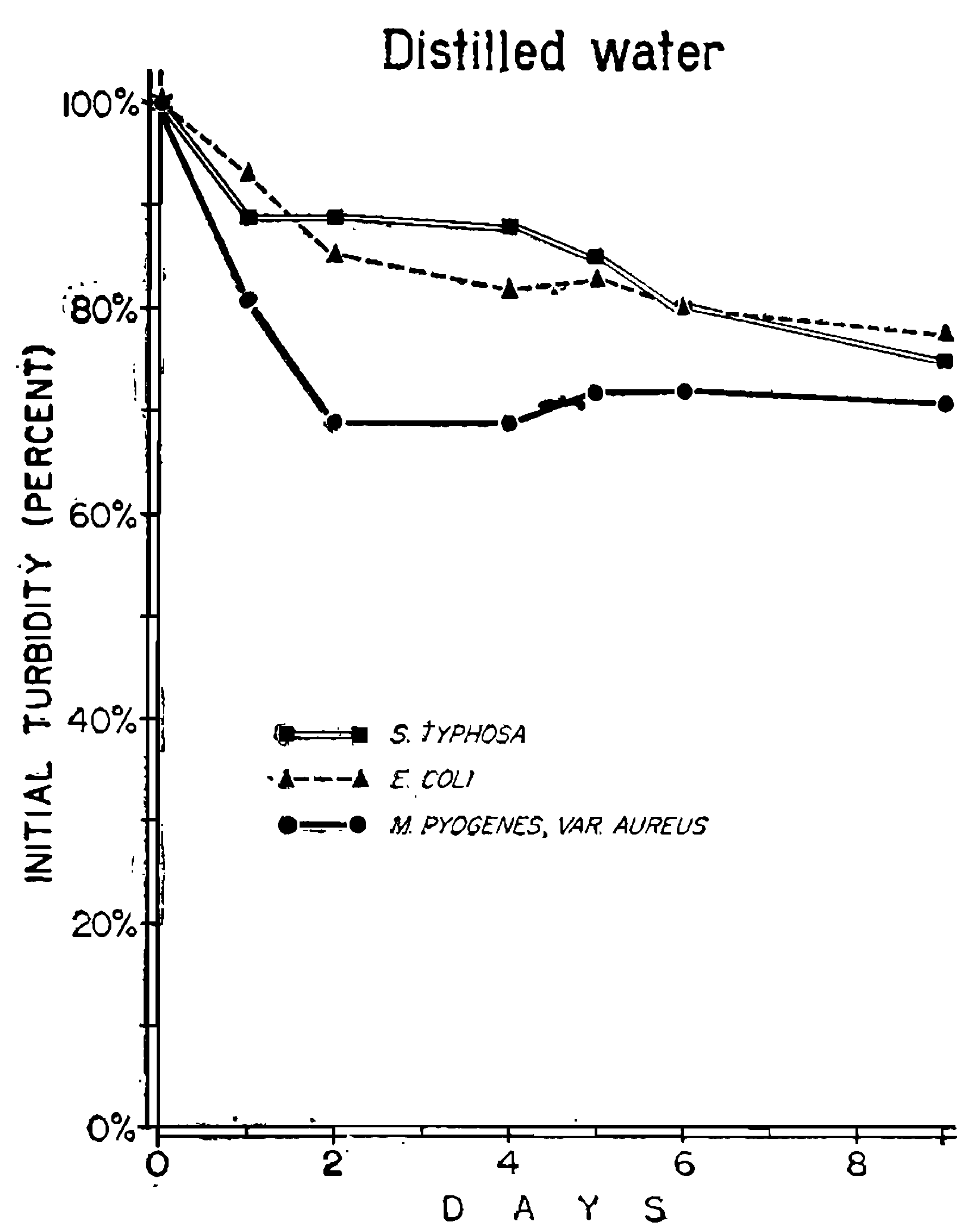

FIG. 14 


\section{TRANSLATION}

\section{Bacteriolytic Action of Phosphates}

(Bacterial Phosphatolysis)

In previous papers $P_{A C H E C O}$ and ABREU (1949) reported the lytic action of phosphates on certain bacteria, and PACHECO and ECHÃNIZ (1953) described the lytic and bactericidal activity of $\mathrm{Na}_{2} \mathrm{HPO}_{4} \cdot 2 \mathrm{H}_{2} \mathrm{O}$ on Salmonella typhosa and Esckirichia coli.

In the present paper some experiments conducted in order to observe a possible difference in the bacteriolytic action of phosphates are described.

\section{MATERIAL AND METHODS}

The salts used were $\mathrm{NaH}_{2} \mathrm{PO}_{4} \cdot \mathrm{H}_{2} \mathrm{O} . \mathrm{Na}_{2} \mathrm{HPO}_{4} \cdot 2 \mathrm{H}_{2} \mathrm{O} . \quad \mathrm{Na}_{3} \mathrm{PO}_{4}$. $12 \mathrm{H}_{2} \mathrm{O}$ and $\mathrm{K}_{2} \mathrm{HPO}_{4} . \mathrm{H}_{2} \mathrm{O}$, in $\mathrm{M} / 10, \mathrm{M} / 50, \mathrm{M} / 100, \mathrm{M} / 500$ and $\mathrm{M} / 1000$ or $1: 100$ and $1: 1000$ solutions.

The microorganisms used were S. typhosa H901, E. coli and Micrococus pyogenes, var. aureus, all from our culture collection. They were grown during 24 hours on agar slants and washed twice in distilled water. Only some drops of a concentrated suspension were needed to obtain in the phosphate solutions an adequate concentration.

The salt solutions were dispensed in $13 \times 100 \mathrm{~mm}$ Kimble test tubes matched for use in a Klett-Summerson photoelectric colorimeter. To the solutions the concentrated suspension of the microorganisms to be tested was added. The final suspension thus obtained gave a direct reading of 100 or a little more in the Klett-Summerson colorimeter equipped with a green filter $(540 \mathrm{mu})$ and using the pure solution of phosphate as the blank. The readings in the colorimeter were made almost daily and the results recorded in percent of the initial readings (increasing or decreasing of the opacity).

The tubes were maintained at room temperature and the microorganisms were found to be alive unless otherwise stated. Otherwise the microorganisms were killed, or the tubes weere sealed in certain experiments.

\section{RESULTS}

Experiments using $\mathrm{Na}_{2} \mathrm{HPO}_{4} \cdot 2 \mathrm{H}_{2} \mathrm{O}$ in $1: 100$ and $1: 1000$ dilutions and $M$. pyogenes and $E$. coli as test organisms showed that this salt was very active as a lytic agent against $M$. pyogenes in the various conditions tested: sealed and open tubes, $37^{\circ} \mathrm{C}$ and room temperature, alive and dead microorganisms (killed with ether) (Figs. 1 and 2). Against $E$. coli, in the same conditions its activity was less intense (Figs. 3 and 4).

Tests with $\mathrm{NaH}_{2} \mathrm{PO}_{4} . \mathrm{H}_{2} \mathrm{O}$ in various solutions showed different results according to the microorganism employed: $S$. typhosa was lysed in all concentrations tested but in a lower intensity than with distilled water (Fig. 5); $E$. coli was more intensely lysed in presence of $M / 10$ and $M / 1000$ concentrations but less in other concentrations used (Fig. 6); $M$. pyogenes was lysed almost in the same grade as in presence of distilled water (Fig. 7). 
In other preliminary experiments, however, the lo'wer concentration $(\mathrm{M} / 1000)$ was more active than the stronger concentrations.

The $\mathrm{pH}$ of the solutions (measured with glass electrode) were the following: $\mathrm{M} / 10,4.5 ; \mathrm{M} / 50,4.75 ; \mathrm{M} / 100,4.92 ; \mathrm{M} / 500,5.07 ; \mathrm{M} / 1000$, 5.32 .

With $\mathrm{Na}_{3} \mathrm{PO}_{4} \cdot 12 \mathrm{H}_{2} \mathrm{O}$ the results were somewhat different than those obtained with $\mathrm{NaH}_{2} \mathrm{PO}_{4} \cdot \mathrm{H}_{2} \mathrm{O}: S$. typhosa was lysed a little less than with distilled water, as occurred with $\mathrm{NaH}_{2} \mathrm{PO}_{4} \cdot \mathrm{H}_{2} \mathrm{O}$ (Fig. 8); E. coli, however, was intensively lysed in all concentrations, the highest concentrations being more active (Fig. 9); $M$. pyogene's var. aureus was completely lysed in presence of $M / 500$ and $M / 1000$ concentrations (Fig. 10). The $\mathrm{p}_{\mathrm{H}} \mathrm{H}$ of those solutions were the following: $\mathrm{M} / 10,11.4 ; \mathrm{M} / 50,11.5$; $\mathrm{M} / 100,11.35 ; \mathrm{M} / 500,9.6 ; \mathrm{M} / 1000,7.43$.

In preliminary experiments it was observed that dead microorganisms were readily lysed in presence of $\mathrm{Na}_{2} \mathrm{HPO}_{4} .2 \mathrm{H}_{2} \mathrm{O}$. Then three phosphates were tested, in $\mathrm{M} / 10$ and $\mathrm{M} / 100$ concentrations (Fig. 11, 12,13); the three species of microorganisms were suspended in the phosphates after they have been killed with ether (evaporated overnight in an incubator). In the experiment, alive microorganisms were tested in the presence of distilled water (Fig. 14). The results showed that $\mathrm{Na}_{3} \mathrm{PO}_{4}$. $12 \mathrm{H}_{2} \mathrm{O}$ in $\mathrm{M} / 100$ concentration was the most active lytic solution.

\section{DISCUSSION}

Bacterial lysis may be produced by the action of antibodies, ageing and death of microorganisms as well as chemical or physical agents. The mechanism of lysis, however, is always represented by rupture of the cell wall.

The first observation of bacterial lysis by phosphates was made by Evangelinos and Wohlfeil (1939) with E. coli. They measured the lysis by the increase of the proteic content of filtrates of suspensions of the microorganisms in $M / 15, M / 30$ and $M / 60$ sodium phosphate. All these concentrations were active. Proteus bacilli were more lysed in the presence of lowest concentrations. The lysis was more intense in temperature ranging from $37^{\circ} \mathrm{C}$ to $45^{\circ} \mathrm{C}$.

Welsch, Salmon and Heusghem (1949) observed that spontaneous lysis of staphylococci determined by a "staphylolysine" was increased by the addition of 0.1 per cent potassium phosphate. When all the phosphates were removed from the broth with calcium or barium carbonate the lysis also occured.

Welsch and Salmon (1949) observed also that $\mathrm{K}_{2} \mathrm{HPO}_{4}$ activated fluids completely inactive or less active due to excessive dilution. In the case of $\mathrm{KH}_{2} \mathrm{PO}_{4}$ the activity was lower in the same circunstances. Dead bacteria were lysed like the alive, showing that the fenomenon is different from that observed by Welsch (1949).

Welsch and Salmon observed yet that staphylococci suspensions washed three times were almost not lysed, but the addition of 0.1 per cent $\mathrm{K}_{2} \mathrm{HPO}_{4}$ determined a rapid lysis which they accounted for an activation of the lytic principle ("ferment") by the phosphate, which became needed 
for the bacteriolysis by its "bacteriolytic" ferment. In other side the washing of the bacterial suspension reduced enormously the lytic action of its ferment, "reactivated" by phosphate addittion, as refered by Welsch.

The work of Welsch and his coworkers admits the existence of a bacteriolysine which may be inespecific acording to Smolier (1949) or specific as admitted by Welsch (1949).

Our results show that phosphates have a lytic activity which is sometimes very intense. Welsch and Salmon observed the influence of phosphates upon spontaneous bacterial lysis but the fluid in which the microorganisms were suspended always contained phosphates, except in the work reported with Salmon and Heusghem, when they intended to have eliminated the phosphates from the medium, but it is possible a previous intracelular ingress of fosfates before its elimination.

Our observations of bacterial lysis in presence of small amounts of certain phosphates seem to be of importance because it is a common observation that bacterial lysis occurs in ageing of broth cultures and it is known that liquid media have always a certain amount of phosphates. Mello and coworkers (1951) observed, also, the rapid decrease of the number of Brucella when microorganisms were suspended in phosphate buffer. Certain Gram positive cocci are very sensitive to the lysis and it is common to observe their disappearence in blood cultures in liquid media.

\section{SUMMARY}

Bacteria are lysed by phosphates in low concentrations. Differences were observed in the lytic activity according to the salt, the trivalent salt being the more active. The lytic action is not always dependent of the living or dead state of the microorganisms. It seems that this "bacterial phusphatolysis" is of importance for the preservation of microorganisms in culture media or in a simple solution containing phosphates.

\section{BIBLIOGRAPHY}

1) Evangelinos, P. and Wohlfeil, T. W.

1939. Ueber Bakterien autolyse und deren Bedeutung fuer Bakterieller Impfstoffe. Zenth. f. Baút., 144: 129 135.

2) Melio, G. C., Danielson, I. S. and Kiser, J. S.

1951. The toxic efect of buffered saline solutions on the viability of Brucella abortus. J. Lab. Clin. Med. $37: 579-583$.

3) Pacheco, G. and Abreu, M. A.

1949. Ação de uma água radioativa sôbre enterobactérias. Presented before the Congresso Medico do Brasil Central e do Triangulo Mineiro. To be published.

4) Pacheco, G. and Echañiz, J. S.

1956. Ação bactericida e bacteriolítica dos fosfatos. - Brasil Médico, 67: 43-46.

5) SMOLIER, V.

1949. Nouveaux aspects des activités bactériolytiques et bactéricides des Actinomyces. Compt. Rend. Soc. Biol., 143 : 1147-1150. 
6) WELSCH, M.

1956. Ação bactericida e bacteriolitica dos fosfatos. - Brasil Médico, 67 : 43-46. Biol., 143 : 997-999.

7) WelsCh, M.

1949. A propos de l'autolyse du Staphilocoue. Compt. Rend. Soc. Biol. 143: 719-920.

8) Welsch, M., S SAlmon J.

1949. Sils derivés du phosphore et activité barteriolytique du Staphylocoque. Compt. Rend. Soc. Biol., 143 : 1399-1401.

9) Welsch, M., Sialmon J. and Heusghem C.

1949. Importance des phosphates par les activités bactériolytiques du Staphylocoque. Compt. Rend. Soc. Biol., 143 : 1152-1154. 